analysis and information on the Comoro Islands will be of interest and value to Africanists concerned with the Swahili-speaking peoples and with early population movements in the Western Indian Ocean region. Communications may be sent to Martin Ottenheimer, B.P. 8, Domoni, Anjouan, Archipel des Comores.

\title{
African Studies Department at the Hebren University of Jerusalem
}

AN African Studies department has been established at the Hebrew University of Jerusalem as a joint project of the Institute of Asian and African Studies (formerly the Institute of Oriental Studies) and the Eliezer Kaplan School of Economics and Social Sciences. The department offers a programme leading to M.A. degrees in African history and in the social sciences. It is hoped to cover other branches of African studies in the future. Students may continue their training at a postgraduate level in the respective departments. Special attention is paid to the interdisciplinary approach to African studies.

Scholars in Israel have studied at close range problems of building a nation from multiethnic groups, characterized by cultural diversification and uneven educational advantages, as well as the struggle to achieve economic independence. Such problems are common to Israel and the African nations. In framing the teaching and research programme of the new department, prominence is given to the study of the history of Islam in Africa. The chairman of the Committee of African Studies is Professor S. N. Eisenstadt (Sociology), and the department co-ordinator is Dr. N. Levtzion (African History).

\section{Makerere Institute of Social Research}

THE East African Institute of Social Research in Kampala, Uganda, has recently changed its name to the Makerere Institute of Social Research and has been reorganized to integrate it more closely with the various social sciences departments of Makerere University College. Its main function, to organize and conduct independent research studies on the economic, social, and political problems of East Africa, remains the same.

The Institute also aims to provide research experience for young East Africans interested in academic careers, to develop teaching materials for university students, and to undertake contract research for government agencies on short-term policy issues. Research workers at the Institute have access to a working library dealing almost entirely with Africa, card punching and sorting equipment, and a modern electronic computer.

The present Executive Committee of the Institute is composed of Mr. D. G. R. Belshaw, Chairman and Head of the Department of Rural Economy; Professor R. J. Apthorpe, Head of the Department of Sociology; Dr. J. Gugler, Chairman of the Joint Board of Graduate Studies, Professor A. A. Mazrui, Dean of the Faculty of Social Sciences and Head of the Department of Political Sciences; Professor B. Okun, Head of the Department of Economics; and Professor M. H. Segall, Visiting Professor of Social Psychology. There are at present 7 Research Fellows and Associates in'Economics, 2 in Political Science,' 7 in Sociology, and $s$ in Social Psychology.

The Institute has over the past twenty years provided a research centre with which research workers visiting East Africa from overseas may affiliate, as well as publishing research completed through its facilities. In addition to long monographs, the Institute publishes a varied series of East African Studies and a new series of Occasional Papers. Mimeographed annual Conference Papers are available to libraries and interested private scholars. Information about the Institute's publications, current research projects, and procedures for affiliation can be obtained from: The Research Secretary, Makerere Institute of Social Research, P.O. Box 16022, Kampala, Uganda. 